\title{
The Education of Deaf in Higher Education through the Information and Communication Digital Technologies
}

\author{
http://dx.doi.org/10.3991/ijes.v2i2.3815 \\ G. Oliani ${ }^{1}$, L. C. R. Nascimento ${ }^{1}$, E. Rocha2 \\ ${ }^{1}$ Campinas State University (UNICAMP), Campinas, Brazil \\ ${ }^{2}$ Vale do Rio dos Sinos University (UNISINOS), São Leopoldo, Brazil.
}

\begin{abstract}
The appearance of Information and Communication Digital Technologies (ICDT) has propitiated conditions for the Higher Education to become able to explore the communicative, pedagogical and didactic potentialities in courses in the Blended Education mode. Such process enables that new teaching and learning modes contribute for the promotion of different educational programs. We emphasize that the synchronous technologies which enable the audiovisual communication on real time such as the videoconference and the asynchronous technologies such as the Teaching and Learning Virtual Environments (TLVE), which enable, among other issues, the repository creation with the contents in text formats, videos and others. In the present text we will deal with the lived experience with the ICDT during the offering of the Graduation Course in Letters - LIBRAS - Bachelor in the Brazilian Signals Language offered in the Blended Education mode in the period from July 2008 to July 2012 by the Federal University of Santa Catarina (UFSC) through videoconference and of TLVE. Approximately 900 students participated on this course, allocated at the headquarters, the UFSC, and in 14 poles in Brazil, among them the Faculty of Education of the Campinas' State University (UNICAMP), where the experience was developed with the participation of 60 students, being 30 students from the Baccalaureate and 30 students from the Graduation course. The course had as general objective in the Graduation to train teachers to perform in the LIBRAS teaching as first and second language. In the Baccalaureate it had the objective of training LIBRAS translators and interpreters. Even though the UFSC's Project had offered the two course categories, Graduation and Baccalaureate, in the present article we will deal with the Graduation course.
\end{abstract}

Index Terms-Blended Education, Deaf, Information and Communication Digital Technologies, Higher Education.

\section{INTRODUCTION}

The present text deals with the experience lived in the period from July 2008 up to July 2012 during the offering of the graduation course on Letters - LIBRAS (Brazilian Signals Language) - Graduation, in blended education mode, offered by the Federal University of Santa Catarina (UFSC), Trindade Campus, in the city of Florianópolis, Brazil.

We have described the practical experiences with the utilization of Information and Communication Digital Technologies (ICDT) lived throughout the course which, on our understanding, contributed to the pedagogical process for the training of deaf individuals. Many of the issues which are formulated about reading, writing, interpretation, teaching and learning with visual proposals have been investigated, shared and recorded throughout the course's offering, and are brought as a recording form of the quotidian and of rethinking the practices which may serve as guidelines for bilingual teaching proposals for deaf individuals in the Higher Education.

The course which had as focus the integration of the UFSC's social inclusion and diversity policies was implemented by the Distance Education Secretariat, by the Communication and Expression Center (CEC) and by the Education Sciences Center from the Federal University of Santa Catarina. The students' admission, which had questions in LIBRAS, took place through a Special Selective Process from the Permanent Entrance Exam Commission (COPERVE), from UFSC, according to criteria defined by the General Coordination and by the pedagogical team of the course. The course relied on a General Coordination at UFSC and a Coordination on each pole. The Graduation curriculum integralization was organized into eight periods, totaling 3.000 hours distributed as follows: 600 hours as basic knowledge of the area; 1020 hours as specific knowledge; 750 as pedagogical knowledge; 420 hours of practice as curricular component; 420 hours of supervised internship and 210 hours as academic, scientific and cultural activities which focused on the flexible and transversal aspects of the curriculum.

The general objective of the course was that of graduating teachers to perform in the LIBRAS teaching as first and second language, and it was structured with the following support bodies: General Secretariat at the head office and a Secretariat on each pole; Academic Record Sector, housed at UFSC; Pedagogical Coordination; Teaching and Learning Virtual Environment (TLVE); Teachers of the disciplines and Tutors, at the head office and in the poles.

The Pedagogical Coordination had as attribution the general planning of the course, the pedagogical aspects and the analysis and the approval of the didactical material.

The TLVE Coordination had the following attributions: customize the platform in accordance with the pedagogical and graphical demands of the course; producing the videos, the hyper medias and the remaining media materials; preparing the technical teams and the students concerning the exploration of the TLVE technological and media potentialities, and implement and keep the course's site.

The course was offered for 14 poles and the head office, the Federal University of Santa Catarina (UFSC), summing up 15 places for the harboring of the students. The classes took place on Saturdays and Sundays, once a 
month, from 8:00 a.m. to 12:00 a.m. After, from 2:00 p.m. to $8: 00 \mathrm{p} . \mathrm{m}$. Therefore, in the class days it was necessary that the videoconference equipment were prepared until 7:45 a.m. so that UFSC could connect them.

\section{THE LIBRAS LETTERS COURSE AT THE UNICAMP POLE}

Even though for contractual purposes of the head office with the poles the course was considered by the Federal University of Santa Catarina as an offer in the Distance Education, having as reference the head office, when one has as reference the UNICAMP pole the course can be regarded in the Blended Education mode, for the students had activities at distance through the videoconference and of the TLVE and presential activities, with the participation of the tutors on the UNICAMP pole. Aiming at elucidating this affair, we emphasize the concepts of Distance Education and blended education.

Moran says that the Distance Education is the process of teaching-learning, through technologies, where teachers and students are spatially and/or temporally separated. It is the teaching/learning wherein teachers and students are not normally physically together, but may be rather connected, interconnected by technologies, mainly the telematics, such as Internet [1].

The blended education takes place in part of the classroom and another part at distance, through technologies. The distance education may or not have presential moments, but it fundamentally takes place with teachers and students physically separated in the space and or on time, but they may be together through the communication technologies [2].

The Graduation Course in Letters with license in LIBRAS had as objective to train teachers to perform on the teaching of the signals language as first and second language, in which the majority of the students were deaf individuals. Such training was possible on account of all the structure of the course having been offered in LIBRAS. UFSC offered fluent educators in the signals language and reconstructed a curriculum which met the peculiarities of the students, in this case, deaf. Thus, the course's objective, apart from the academic formation, was that of the dissemination of the deaf difference, in the capacity affirmation of these individuals, complying with the Decree in force, which states the need to offer courses which graduate LIBRAS teachers to meet the open disciplines of graduation in higher teaching.

The offering of the course came in the wake of several political attitudes, resulting in the mobilization of the deaf themselves by the recognition of its language and by the insertion of LIBRAS on its educational processes. To have LIBRAS deaf teachers was revealed as a necessity, in that moment, to meet two requirements of the Decree $5.626 / 05$, i.e.: to have deaf teachers to compose the staff of teachers in the schools and classes which were being structured within a process of bilingual education for deaf children and youngsters, and promoting the graduation of teachers for the university courses of teachers formation.

The course was ministered in the physical facilities of the videoconference room of UNICAMP's Education Faculty, in the campus of the city of Campinas, state of São Paulo, Brazil. In this place there occurred the classes through the videoconference system simultaneously connected with the head office, the Federal University of
Santa Catarina, and with the remaining poles. The presential classes took place at Faculty of Education conventional classrooms, where the students participated of presential activities with the tutors from the pole making use of the available technological resources on it, such as: microcomputers; notebooks; multimedia projectors, DVD devices; camcorders, wideband internet and others.

We may teach and learn with programs which include the best of the presential education with the new forms of virtual communication. There are moments in which it is worthwhile to meet physically - in the beginning and in the end of a subject or of a course. There are others in which we learn more by being each one of us on his usual space, but connected with the remaining colleagues and professors, for a constant interchange, turning real the concept of permanent education [2].

To offer the course and propitiate conditions for the harboring of the students, the UNICAMP pole relied on the following teams: a coordination; a tutor with fluency in the signals language, an interpreter for the pertinent communication with academic activities with the secretariat of the pole; a technical support team; an academic support team; infrastructure support teams such as security, cleaning, feeding and others. All the teams performed as if they were one single team. Each team with its contribution propitiated appropriate conditions to receive the students during the presential meetings and to enable the offering of the course to them.

\section{THE STUDENTS}

The students from UNICAMP pole dwelled in different cities from the state of São Paulo, and some of them lived in places with distances of approximately $600 \mathrm{~km}$ from the city of Campinas, what demanded the estimated time of nine hours of commuting time by land means for the students to watch classes at Faculty of Education. Therefore, the determination of the students to watch the classes through videoconference sessions and to participate on the presential activities with the tutors had to be recognized by all the members of the pole's team. Moreover, it was necessary that the pedagogical team of the pole motivated the student to his intensive participation in the classes and in the activities with the tutors, so that conditions were propitiated in order to have a higher interaction among all: students, teachers and tutors, so that it was minimized the students evasion rate from the course. Masetto, Almeida, Moore and Belloni, argue that the interaction is considered one of the factors which may contribute the most with the good quality of the courses in the blended mode using the Information and Communication Digital Technologies and which may minimize the evasion rate of students from a course [3], [4], [5], [6].

Before the determination of the students to move on up to the city of Campinas, it was indispensable that all the members of the team of the UNICAMP pole fulfilled their attributions with agility, dynamics and commitment. Moreover in order to propitiate conditions for the classes to take place with success, efficiency and efficacy, and in conformity with UFSC's class calendar. It is emphasized that for the success of a course in the blended mode, the members of the pole's team must have knowledge about the theoretical concepts and if possible of the practice of such education modality. Furthermore, it must be propitiated a compatible structure with the demand of the course 
regarding: the academic content; the administrative activities, the technological infrastructure; the building infrastructure and the general support to the students, even though these are not the sole conditions for the success of a course in the blended mode. One must focus on the content, on the didactic, on the teaching methodology and in other pedagogical factors.

In the beginning of the course, in July 2008, the students were with the age bracket between 18 and 38 years of age. These students presented dynamic behaviors to the actions pertaining to the activities assigned by the teachers from the head office, the UFSC, during the videoconference sessions, for immediately after the teacher having assigned a given activity to the students from UNICAMP's pole, in a short moment they submitted their activities in LIBRAS as a response to the question presented by the professor. Personal presentations were used, in LIBRAS, and of media contents in the video form, created by the students themselves during the course of the class.

Masetto, says that the images place both teachers and students working and learning at distance, dialoguing, discussing, researching, asking, replying, communicating information through resources which enable such interlocutors living on the most faraway places, to get together and enrich themselves with mutual contacts [7]. The video creation, recorded by the students themselves in different environment to those of the videoconference room, took place through photographic cameras, from camcorders and notebooks. All the technologies used for such activities were property of the students themselves. Such creation took place concomitantly with the class ministered by the UFSC teacher by means of videoconference. The teacher has a great range of methodological options, of possibilities to organized his communication with the students, of introducing an issue, of working with the students presentially and virtually, and of evaluate them [2].

It was observed the initiative and the creativity of the students to meet the demands of the head office under the aspect of the class content. Furthermore, the agility for the students to create and submit the media contents pertaining to the issues of the subjects presented by the head office, with presentations in form of signals, of images, of texts and, or videos. They are students which, on its majority, had affinity with the technology usage, both for its utilization as pertinent activities to the content of the classes through videoconferences, as for the development of other academic activities, in the form of video, to be created as complement to the presential activities.

The videos, when used propitiate to the students the discussion, analyses, comparisons, changes between projection and debates allowing the student to place himself before realities which perhaps he would not get to know, or would hardly become aware of them, if it was not for such resource [7].

It was observed by the author, who also was present in all the classes through videoconferences that up to $15 \%$ of the students used notebooks, netbooks and mobile devices with wireless connection, such as smartphones and cellular phones for the development of their activities in the Faculty of Education videoconference room.

Initially, 30 deaf students were admitted through the entrance exams, and in the first quarter of 2008 some of them gave up the studies, among others, for the following reasons: three students did not bear affinity with the content of the course; one student had commuting difficulties from his city up to the UNICAMP's pole, for he had to move on a distance of approximately $500 \mathrm{~km}$ to watch the pole's classes and, one student, in the case of the capital of the state of São Paulo, did not have technological resources, such as computer and access to internet, what made it impossible for him to access the content of the classes by means of the Teaching and Learning Virtual Environment. There was also a student which could not remain in the course due to difficulties to regularize the documentation concerning her enrollment. After the mentioned dropouts, there happened a second summoning to the candidates of the entrance exams for the fulfillment of the remaining vacancies. Of the incoming students, approximately four of them were graduated on higher level in other courses not specific from LIBRAS.

\section{THE TECNOLOGIES}

Before the necessity of preparation of the technological infrastructure for the poles and the head office, UFSC elaborated all the logistic for: acquisition, delivery, installation, configuring, tests and activation of the videoconference equipment. New equipment were acquired for all the poles in order to minimize the possible technical difficulties which could stop the offering of the classes by means of videoconferences. Moreover, the referred acquisition had per objective to standardize the equipment model to equalize the trainings and enable the logistics to: the configurations; the management and the equipment maintenance.

Nevertheless, the UNICAMP's pole used the videoconference room from Faculty of Education, implanted in 2004 and built under an appropriate pedagogical conception for courses in the Blended Education mode and Distance Education.

\section{THE VIDEOCONFERENCE}

The integration of technologies on Higher Education is modifying the teaching and learning modes. For the teaching and learning process with deaf students with and through videoconference, it must be propitiated to the students follow up and differentiated support, when this support is compared with other offered to the listener students.

The video for the deaf, with all the signal modes and non-manual expressions, such as facial and corporal ones, is the way through which such individual acquires the knowledge through a videoconference.

As the virtual communication technologies advance, the presentiality concept is also changed. We may have external teachers sharing given classes, and an outside teacher "walking in" through videoconference in my class. There will be a much bigger interchange of teachers, through which each one will collaborate in some specific issue, many times at distance [2].

The videoconference is the audiovisual communication means which resembles the most to the presential communication, since this enables to the participants a visualization of images in real time, with movements in all the senses, with gestures, facial expressions and of all the corporal communication modes that the individuals may manifest to dialogue. 
Cruz says that the videoconference propitiates interaction forms, affective and logistical questions which demand the familiarization of the teachers, for the teacherstudent intermediation demand differentiated teaching and learning strategies to those used in the presenctial classroom [8], [9].

For the deaf, the image is of relevant importance, since the audio is not present. Thus, it is indispensable that the videoconference equipment have capacity for capture, for the processing, for the processing and for the transmission of images of individuals with constant movements, in this case, images of teachers and of students getting in touch with each other by means of LIBRAS. Furthermore, the equipment must have capacity to process the files in data form, text, images and videos in order to be able to transmit them to the remaining videoconference rooms in the appropriate mode, which enables the visualization of static images or else those in motion without their pixelization.

In complement to the resources of the videoconference equipment, the multiservice networks must support the demanded traffic during the classes, as well as there must be availability of local equipment, in the facilities of the Teaching Institutions and in all its ways, which enable both the image transmission and reception without data package losses, so as to avoid the generation of image granulation, much less the delay in the reception of the transmitted images by the remaining videoconference classrooms. This assures the synchronous visual communication among the teachers and the students, and allows that all the LIBRAS generated signals may be captured and transmitted so that the receiving students of such images, which are in the remaining videoconference classrooms, understand them. Therefore, both the videoconference equipment and the multiservice networks must have available both processing and traffic capacity, respectively, to assure the transmission of the class without the loss of any signal type for the deaf individuals. If this does not happen, the LIBRAS communication and interpretation might be fragmented, what could harm the subject comprehension of the ongoing class.

For the connections with all the poles' videoconference equipment, the Federal University of Santa Catarina used an equipment named Multipoint Control Unit. Through such equipment it was achieved the connection management of the videoconferences from all the poles, including: the connection velocity; the image quality; the image presentation layout of all the videoconference classrooms in the video monitors; the content exhibition of the media archives of the teachers' classes from the head office and from the students in the pole's videoconference rooms.

In the beginning of the course, in July 2008, some network processing difficulties were found during the first videoconference sessions, including on the course's inauguration day, what impacted in the quality of the images received from the head office. Other problems were detected, such as the processing and traffic capacity of the UFSC equipment for the teachers, the tutors and the students to access the TLVE. Immediately after these technical problems had been detected, UFSC provided solutions so that the course were developed in conformity with the expectations from the poles' teachers, tutors, students and technical support teams.

\section{THE VIRTUAL ENVIRONMENT FOR TEACHING AND LEARNIG}

As Teaching and Learning Virtual Environment, the Federal University of Santa Catarina adopted Moodle, where UFSC hosted videos generated during videoconferencing sessions for students to review lessons as Video on Demand through networks multiservice. At the same TLVE teachers and tutors posted content classes in media formats.

The TLVE has been customized and hosted on UFSC's equipment. The crew of the university managed the logistics for the deployment of technology infrastructure from headquarters. Before the course starts, technicians and teachers from UFSC prepared the technical support teams from headquarters and the poles. Also provided technical support to the teams of the poles during the course. Almeida argues that the TLVE adopted, provides that everyone talks to everyone at different times over pertinent to their pre-occupation issues, but always ensuring the feeling of being together virtually as the feeling of being with each other independent of space and time [10]. While most of the tools TLVE is asynchronous, any technology can be used by the chat tool as a means of synchronous communication.

Some activities practiced with the TLVE were: the use of synchronous communication tools such as chat and forums, such as asynchronous communication.

In these spaces, student-student and student-tutor relationship facilitated an extensive exchange of experiences in which the knowledge was shared, providing academic enrichment. Vygotsky says that the learning is vital in the process of cognitive development, which means, the learning drives development [11]. Therefore the importance of education, teaching, teacher and more experienced partners as elements of mediation. The tests applied to students occurred at the end of each discipline in conventional classrooms of the Faculty of Education at UNICAMP, using printed paper material and videos available on links sent by UFSC to the pole UNICAMP, one day in advance of the tests. The tests were given in the form of videos in LIBRAS using microcomputer, multimedia projector and multiservice from the Faculty of Education's conventional classrooms network.

We focus this paper on the use of videoconferencing and Virtual Environment for Teaching and Learning and Digital Communication and Information Technologies used during the course, however, it has also adopted other technologies, such as streaming, videos, microcomputers, notebooks; DVD players, multimedia projectors and multiservice networks.

\section{THE MEDIA CONTENT}

Knowing that in the class for deaf students there is no audio, the preparation of the media content from teacher's classes have to be presented in a legibly form, suitable for presentation, and through videoconferencing.

Initially, the texts of media files of teachers were being presented in a way that became barely legible on the video monitors from the videoconference's rooms of the poles. As soon as the monthly reports of activities were initiated, the technical support team from the polo of UNICAMP, suggested to technical support from headquarters staff to adopt a standard slide template to elaborate the media content from headquarters, the same model used for the 
pole preparation of media content classes in the videoconferencing room in EF.

Mantoan and Baranauskas bring to light that for deaf people who use sign language, it is essential the presence of interpreters that meet the social and educational demands; the expansion of the language, so they have more independence in communication; learning Portuguese as a second language, and resources that emphasize the visual. When they are not users of sign language and use speech and lip reading for communication, require other physical (oralist interpreter) and technological (subtitles, software, video and multimedia products, and others) resources, facilitating the access to information [12].

Thus, texts, images, figures of teachers media content should be prepared in a way that can be ensure the viewing of such content to deaf students, during videoconferencing sessions through streaming with the transmission through multi-service networks and as Video on Demand, after school. Underscores the importance of the presentation of the texts, because after recording the videos, these are compressed, which can impact the quality of it with respect to the video generated and transmitted in real time by means of videoconferencing equipment, in other words, if the texts do not present appropriate fonts and colors, deaf people may have difficulty reading these, especially after the compression of the videos to the video hosting servers for the review classes.

\section{WHO IS THE DEAF PEOPLE?}

It's important to strengthen that the vision of deafness that apply to the proponents and teachers of this course is far from the medical discourse that deafness is a disability. Lodi, Skliar argue that deafness is understood as a linguistic difference within an approach that became known as socio-anthropological view of deafness [13], [14]. Deaf people form a minority language community characterized by sharing a sign language and cultural values, habits and way of own socialization. (...). The sign language overrides linguistic desability consequence of deafness, and allow the deaf, then, to constitute a different minority language community and not a deviation from normality [14].

Therefore, deafness is seen as a visual experience and the deaf as a linguistic minority group. In this perspective, deafness is placed outside the discourse of disability. Celia argues that the deaf is not a disease that needs to be cured, but a guy who has a natural language, sign language, with the Portuguese a second language [16]. Skliar, Deafness can be defined in this paradigm as the political difference as visual experience, characterized as multiple identities and located within the discourse of difference [15]. Being deaf a person who constitute himself by visuality, the strategies by which accesses the knowledge are also visual and these were valued during the course Letters LIBRAS with and through videoconferencing technology.

The learning of each individual is intrinsically related to their experiences in interacting with other human beings [11]. The author emphasizes the role of culture in the formation of each person and the construction of their cognition. The interaction between individuals plays a key role in building the human being: it is through interpersonal relationship that the individual internalizes the culturally established forms of psychological functioning. Therefore, social interaction with other members of the culture provides raw material for psychological development.

Believing these assumptions, the experience we had at the course Letters LIBRAS, each tutor stood as a mediator in the construction of knowledge of their students, thus enriching their own knowledge. The acquisition of knowledge is given in the interaction between the participants that comprised this educational process in the following ways: tutor - student, student - student, student teacher. This last, by virtually ways, through video classes and video conferences. During the videoconference interaction between teacher and student was given in real time, directly, through questions and answers in LIBRAS.

Human communication occurs primarily through language, and this has a fundamental role in the development of the people. Therefore, the development of the concepts in this course could not be otherwise than in a language accessible to the deaf, the LIBRAS. This language has a fundamental role in the development of the deaf, it expands your universe and freed from immediate perceptual world, allowing to imagine, create, dream, learn, teach, grow in capability and relationships. Thought and language are inextricably linked, it is not possible for a human being to occur without the other. The Thought is not merely expressed in words, it is through them that he comes into existence [11].

The relationship between thought and language is a living process; thought is born through words. A word devoid of thought is a dead thing, and an unexpressed thought in words remains in the shadows [11].

Deaf people comprised the teaching staff of the course Letters LIBRAS and this fact is not only important for its ability to improve access to knowledge by students, but by having created a break with tradition in higher education courses in which were inserted the deaf where there has always been exclusively listeners teachers. Therefore, there was the beginning of a new discourse that broke with the discourses of an inclusion that operates on exclusion, bringing possibilities of other forms of learning, and new ways to make the inclusion of deaf people. So that this respected, in fact, the singularities of these students: the use of LIBRAS in all teaching processes, the presence of deaf teachers, and the use of educational and methodological strategies for teaching deaf.

The innovation of the Bachelor's Degree Letters LIBRAS was the possibility of an authentic conversation between teachers and students, tutors and learners, deaf and hearing, making that moment a real inclusion, a proposal also supported by [17], when he states that or means pedagogy as conversation with others and between others, or leave for others to regulate those that are 'almost' like 'us'. So similar, but never identical.

The conversation, listening to each other, the exchange and interaction open up the possibility to break the colonial imposition which the deaf have been and continue to be submitted in the educational process for years. To understand the speech of another person is not simply understand his words - have to understand his thinking. But even that is not enough - you also need to know the motivation [11].

\section{RESULTS OBSERVED}

Most students who completes the graduation, continued with studies and five of them joined in postgraduate 
courses in lato sensu categories and a student enrolled in the course of post graduate studies in traditional classroom course in a private university in São Paulo.

It is worth adding that the degree course in Arts LIBRAS received maximum concept of the Ministry of Education of Brazil (note 5) in the recognition process and the polo UNICAMP was highlighted between the poles that hosted the course, once an undergraduate student was awarded a certificate and student merit medal for the best performance among all students at all centers and headquarters. The portal UNICAMP presented the following statement of the student: A degree in Literature - LIBRAS was very important, because I had the opportunity to seek information, knowledge, learning, experience, and from there, get the academic and professional recognition", according to [18]. This was the writing of the text of the email of the student. Plus the news came the commentary on the current professional life of the students stating that currently, he teaches LIBRAS in the city of Taboão da Serra in the Center for Integration and Support for Hearing and Visually Impaired (CIADEVA), located in the state of São Paulo in Brazil. Said student is also a professor of extension, graduate and undergraduate LIBRAS University of Santo Amaro (Unisa).

\section{CONCLUSION}

This paper brought an experience about higher education to the academic dialogue of the deaf people. We believe that the process of teaching and learning and exchanges lived in polo UNICAMP gave satisfactory conditions to the formation of the students, both as regards the use of educational content as about the use of Digital Technologies of Information and Communication. In the experiment we found that during the offering undergraduate Letters LIBRAS many horizons were visualized in the sense of considering the need of training for deaf people to visual mode, with and through the use of Digital Information and Communication Technologies that are proven contributed to the implementation of visuality.

Media content for the offering of courses in blended modality for deaf people using videoconferencing and TLVE, should be prepared in even more formats suitable when compared to the people content for listeners, because the visual communication for deaf people is more relevant for listeners. Teams of technical support poles should be committed to the course, with teachers, with students, with content and all the other teams. They must have knowledge of the concepts of offering courses in blended mode. One cannot consider the offer of courses just like the use of technology, but as generation, transmission and production of knowledge. These teams must work intensively with initiatives for instant alternative technological solutions with agility, and initiatives that failures do not occur that can impact the loss of any transmission and or receipt of classes through videoconferencing.

\section{REFERENCES}

[1] J. M. Moran, $O$ que é educação a distância, (2002). http://www.eca.usp.br/prof/moran/site/textos/educacao_online/dist .pdf

[2] J. M. Moran, Novas tecnologias e mediação pedagógica, Campinas: Papirus, 2012, pp. 32-58.

[3] M. Masetto, Competência pedagógica do professor universitário, São Paulo: Summus, 2003.
[4] M. E. B. B. Almeida, "Educação, ambientes virtuais e interatividade," in: Educação on-line: teorias, práticas, legislação, formação corporativa, M. Silva, Org. São Paulo: Loyola, 2003.

[5] M. G. Moore, Educação a Distância: uma visão integrada, São Paulo: Cengage Learning, 2008.

[6] M. L. Belloni, Educação a Distância. Campinas: ed. Autores Associados, 2008.

[7] M. Masetto, "Mediação Pedagógica e o uso da tecnologia," in: Novas tecnologias e mediação pedagógica, Campinas: Papirus, 2012, pp. 150-152.

[8] D. M. Cruz, M. Moraes, e S. Pereira, "Avaliação da aprendizagem na pós-graduação por videoconferência e internet," in: Avaliação da aprendizagem em educação online, M. Silva, e E. Santos, Orgs. São Paulo: Loyola, 2006, pp. 471-484.

[9] D. M. Cruz, M. Moraes, e S. Pereira, "Aprendizagem por videoconferência," in: Educação a Distância: o estado da arte, F. Litto, e M. Formiga, Orgs. São Paulo: Pearson Education do Brasil, 2009 , pp. $87-93$.

[10] M. E. B. B. Almeida, e J. A. Valente, Formação de educadores a distância e integração de mídias, Orgs. São Paulo: Avercamp, 2007, pp. 128-156.

[11] V. L. S. Vygotsky, Pensamento e Linguagem. São Paulo: Martins Fontes, 1998, pp. 156-190.

[12] M. T. E. Mantoan, e M. C. C. Baranauskas, Autores da inclusão na universidade: formação e compromisso, Campinas, Unicamp, Biblioteca Central Cesar Lattes, 2009, pp. 75-76.

[13] A. C. B. Lodi, "Educação Bilíngüe para Surdos". in: Fonoaudiologia: Surdez e Abordagem Bilíngüe, C. B. F. Lacerda; H. Nakamura; M. C. Lima, Org. $1^{\text {st }}$ ed., vol. 1, São Paulo: Plexus, 2000, pp. 60-79.

[14] C. Skliar, "Uma perspectiva sócio-histórica sobre a psicologia e a educação dos surdos," in: Educação e exclusão - Abordagens socioantropológicas em Educação Especial, Org. Porto Alegre, Mediação, 1997, p. 141.

[15] C. Skliar, Atualidade de educação bilingüe para surdos, Org. vol. 1. Porto Alegre, Mediação, 1999, p. 11.

[16] L. S. Celia, "Aprendizagem da Segunda Língua: Experiência vivenciada em grupos com adolescentes surdos," in: $O$ Admirável mundo dos surdos, M. C. Danesi, Porto alegre: PUCRS, 2001, p. 129.

[17] C. Skliar, As armadilhas de um sistema de exclusão. Interview. Newspaper Folha Dirigida. Teacher's day special (2003).

[18] www.folhadirigida.com.br/htmls/Hotsites/Professor_2003.

[19] [18] UNICAMP, State University of Campinas. Aluno surdo da Unicamp recebe medalha de mérito estudantil, (2013). http://www.unicamp.br/unicamp/noticias/2013/05/17/aluno-surdoda-unicamp-recebe-medalha-de-merito-estudantil

\section{AUTHORS}

G. Oliani is with the State University of Campinas (UNICAMP), Faculty of Education, Campinas, Brazil. He is engineer and is the Director of Distance Education and Information and Communication Technologies. He is Phd student in the Graduate Program in Education at the Faculty of Education at UNICAMP. University City "Zeferino Vaz", Bertrand Russell Street, 801, CEP 13083970, Campinas, Brazil. (e-mail: g_oliani@hotmail.com).

L. C. R. Nascimento, is with the State University of Campinas (UNICAMP), Faculty of Education, Campinas, Brazil. She is professor at Faculty of Education at UNICAMP. University City "Zeferino Vaz". Bertrand Russell Street, 801, CEP 13083-970, Campinas, Brazil. (e-mail: lcrn05@yahoo.com.br).

E. Rocha is with Vale do Rio dos Sinos University (UNISINOS), São Leopoldo, Brazil. She is $\mathrm{PhD}$ student in Graduate Program in Production Engineering at University of Vale dos Sinos (UNISINOS). Unisinos Avenue, 950, Cristo Rei, São Leopoldo, Brazil, CEP 93022-000. (email: eleniser@unisinos.br).

Submitted 29 April 2014. Published as re-submitted by the authors 18 May 2014. 